\title{
O aprofundamento das relações do Brasil com os países do Oriente Médio durante os dois choques do petróleo da década de 1970: um exemplo de ação pragmática
}

Intensifying Brazil's relations with Middle East countries during the two oil crises of the 70's: an example of a pragmatic action

CARLOS RIBEIRO SANTANA

Rev. Bras. Polít. Int. 49 (2): 157-177 [2006]

Introdução

Um problema diplomático da agenda de política externa pode advir de diversos fatores, como, por exemplo, a macroestrutura internacional, as circunstâncias geográficas e as necessidades internas do país. Tal era o caso do choque do petróleo, em 73, que provinha da conjuntura internacional e afetava diretamente o Brasil, extremamente dependente desse insumo. Com efeito, o país era à época o principal importador de óleo no mundo em desenvolvimento.

A intensificação da aproximação com o Oriente Médio, a qual preencheu certos vazios diplomáticos da atuação brasileira, está associada à crise energética da primeira metade da década de 1970 e ao projeto nacional de desenvolvimento econômico. Diante da alta do preço do petróleo, equilibrar a balança comercial com os países daquela região e garantir o fornecimento de óleo em contexto internacional de instabilidade política consistiam questôes cruciais para o país. Com efeito, durante o período em tela, o Brasil logrou diversificar sua agenda bilateral - estabelecendo relações diplomáticas com cerca de dez Estados da região -, haja vista a esperança de atrair novos mercados para as exportaçóes nacionais.

Desde o final da década de 1960, a diplomacia brasileira vinha conferindo ênfase ao comércio exterior e à busca de mercados para os produtos da incipiente indústria nacional, bem como à necessidade de garantir o abastecimento de

* Diplomata e mestre em Relaçôes Internacionais pela Universidade de Brasília - UnB. O presente artigo reflete apenas as opiniōes do autor e não busca representar as posiçōes do governo brasileiro (carlosribeirosantana@gmail.com). 
petróleo, atitude que levou à série de iniciativas em direção ao Oriente Médio em meados da década de 1970. No presente artigo se analisa o ensaio da política externa brasileira frente aos Estados árabes durante a década de 1970, englobando, os governos Médici, Geisel e Figueiredo. É importante ressaltar que grande parte das fontes primárias disponíveis para a pesquisa foi esgotada em trabalhos com os quais se mantém diálogo intenso no artigo.

\section{Linhas gerais do governo Médici}

A auto-intitulada "Diplomacia do Interesse Nacional" (69-74), do chanceler Mário Gibson Barbosa, promoveu algumas alterações de forma em relação à "Diplomacia da Prosperidade", do presidente Costa e Silva. Buscou, na opinião de Vizentini ${ }^{1}$, "uma estratégia individual de inserção, estabelecendo relações essencialmente bilaterais, especialmente em direção aos países mais fracos". A nova orientação da política externa enfatizava as relações bilaterais no horizonte da ação diplomática voltada para a busca do desenvolvimento. No entanto, o multilateralismo do governo Costa e Silva não foi abandonado; só deixou de ser prioridade frente à opção pelo bilateralismo, o qual complementava a atuação multilateral.

Durante a década de 1970, o Itamaraty reforçou duas diretrizes de política externa para o Oriente Médio, tendo em conta o choque do petróleo e os interesses do país. A primeira, a partir de 73 , era pautada pela condenação da expansão territorial de Israel por meio de conflitos armados com seus vizinhos. A segunda, após a Guerra do Yom Kippur, dizia respeito ao apoio à criação do Estado palestino. A nova orientação da diplomacia abandonava a retórica anterior da política de eqüidistância ${ }^{2}$ entre as partes para assumir, na opiniāo de Norma $\mathrm{Breda}^{3}$, caráter de maior realismo, nacionalismo e pragmatismo, posição condizente com as transformações do cenário internacional, mormente a crise do petróleo.

${ }^{1}$ VIZENTINI, P. G. F.. A Politica Externa do Regime Militar Brasileiro: Multilateralização, Desenvolvimento e a Construção de uma Potência Média (1964-1985). 1. ed. Porto Alegre: Editora da Universidade, 1998. V. 1, p. 142 .

${ }^{2}$ A posição da diplomacia brasileira que se seguiu de 47 a 73 em relação ao imbróglio na Palestina não foi de neutralidade, mas sim de eqüidistância. A neutralidade, no caso, significaria desinteresse, abstenção e ausência. A eqüidistância, por sua vez, revelava-se posição única e equilibrada, por meio da qual o país poderia contribuir, ainda que de maneira modesta, para o encaminhamento do conflito árabe-israelensepalestino em conformidade com a tradição pacífica nacional. $\mathrm{O}$ termo eqüidistância, o qual orientou a política externa para o Oriente Médio de 47 a 73, foi desenhado pelo próprio Itamaraty, que mantinha, até então, interesses comerciais tanto com Israel quanto com os países árabes. Além disso, a presença de importantes contingentes judeus e árabes na sociedade brasileira influenciou o posicionamento equilibrado e eqüitativo da diplomacia para a região. Cf. SANTANA, Carlos Ribeiro. O Brasil e conflito árabeisraelense-palestino (1947-2005). Dissertação de Mestrado. Brasília: Universidade de Brasília, 2005, p. 101.

3 BREDA DOS SANTOS, Norma. "O Brasil e a questão israelense nas Nações Unidas: da criação do Estado de Israel ao pós(?)-sionismo”, In: BREDA DOS SANTOS, Norma. Brasil e Israel: diplomacia e sociedades. Brasília: Editora Universidade de Brasília, 2000, p. 20 e 21. 
A iniciativa de aproximação com os países do Oriente Médio abrangia o âmbito político e comercial. Mais do que mera retórica diplomática, buscava resultados concretos, como, por exemplo, garantir o fornecimento de petróleo frente ao encarecimento progressivo das importaçôes de combustível, principal preocupação do governo brasileiro, como será discutido no presente trabalho. A questão do fornecimento desse insumo tornara-se a maior preocupação da diplomacia, haja vista o projeto de desenvolvimento acelerado em curso no país.

A nova política inseriu-se no quadro geral mais amplo de intensificação das relações políticas e econômicas com o Oriente Médio. Produziu novas possibilidades em relação aos países árabes sem, contudo, afetar o relacionamento com Israel, como se verá adiante. No tocante à estratégia diplomática para com a região, houve continuidade de projetos anteriores que buscavam alternativas às relações com os Estados Unidos. A tática visava à consecução de parcerias com potências médias e com países de menor desenvolvimento relativo, de forma a aumentar a autonomia da política externa no cenário internacional.

\section{O primeiro choque do petróleo}

Em outubro de 73, eclodiu a Guerra do Yom Kippur, a que se seguiu a quadruplicação do preço do barril de petróleo, tornando a importação desse insumo questão estratégica para a diplomacia brasileira, a qual buscou, com afinco, aprofundar as relações com os Estados do Oriente Médio. $\mathrm{Na}$ esteira da nova guerra na região, os países produtores de petróleo anunciaram importantes aumentos no preço do produto, o que, para os árabes, visava a despertar a consciência moral do mundo diante do conflito contra Israel. A estratégia política e econômica do petróleo era usada como um meio a mais de enfrentar o imbróglio na região, uma vez que as Nações Unidas não tomavam as medidas necessárias para resolver de vez o problema palestino. Na prática, a guerra criou as condições políticas para o aumento do preço do barril de óleo por meio da ação coletiva dos membros da Organização dos países Exportadores de Petróleo (Opep).

Nesse contexto, o perfil do relacionamento brasileiro com os países árabes teve de ser revisto em 9 de dezembro de 73, quando a Opep aumentou significativamente o preço do petróleo. O impacto do aumento fez com que o Brasil - o maior importador de óleo entre os países em desenvolvimento e o sétimo em escala mundial, em 74 - passasse a gastar cerca de $40 \%$ da receita adquirida em exportações com a importação desse insumo, em 74 . O mesmo percentual, em 72 , girava em torno de $15 \% \cdot{ }^{4} \mathrm{O}$ efeito da enorme elevação do preço efetivo médio do barril de petróleo significou forte revés para o projeto

${ }^{4}$ Idem, p. 56. 
desenvolvimentista perseguido pelo regime militar, o qual dependia, de maneira assaz forte, de insumos energéticos importados.

Dessa forma, o país viu-se duplamente atingido, pois, por um lado, aumentava o preço de um produto do qual era grande importador e, por outro, era praticamente insignificante o volume de exportaçóes brasileiras para a região, de modo a fazer frente ao crescimento vertiginoso do déficit na balança comercial com os países exportadores de petróleo. Nesse sentido, segundo o embaixador Luciano Rosa:

Essas realidades aconselharam uma ofensiva diplomática em direção a uma área que não apenas representava a melhor opção de fornecimento de petróleo ao Brasil como [também] expressivo mercado para produtos não-tradicionais de exportação. Desde logo se tornou patente o imperativo de uma definição mais precisa e melhor fundamentada de nossa posição ante os conflitos no Oriente Médio e, particularmente, a questão palestina, sem o que estariam comprometidos os ensaios de aproximação com os países árabes. ${ }^{5}$

Além disso, no contexto da Guerra do Yom Kippur, os Estados que apoiassem Portugal, África do Sul ou Israel arriscavam-se a ter o fornecimento de petróleo suspenso. Com efeito, em 24 de novembro de 73, foi aprovada resolução entre 15 Estados africanos que incluía o Brasil entre os seis países que sofreriam boicote diplomático no fornecimento de petróleo caso não cessassem o apoio ao governo de minoria branca sul-africano. À ameaça africana, seguiram-se manifestações árabes no mesmo sentido, isto é, ameaças de boicote no fornecimento de óleo a países que apoiassem o expansionismo israelense. Convém lembrar que, à época, o país importava cerca de $80 \%$ do petróleo consumido internamente, estando, destarte, fortemente vulnerável aos efeitos produzidos pela terceira guerra árabe-israelense.

\section{Incremento prático das relações com a região durante o período}

Um pouco antes da eclosão da Guerra do Yom Kippur, o chanceler Gibson Barbosa viajou ao Oriente Médio com o objetivo de incrementar as exportaçôes brasileiras e garantir o abastecimento de petróleo. O aumento paulatino do preço desse insumo ressaltava a importância dos países da região enquanto possíveis mercados consumidores de produtos brasileiros. Com efeito, após o choque do petróleo, a fim de auferir dividendos, bem como evitar represálias, nas relações bilaterais com os Estados produtores de óleo, o Brasil assumiu posição categoricamente pró-árabe nos foros multilaterais. A nova realidade

5 ROSA, Luciano Ozório. "O Brasil e o Oriente Médio (1930-1990)”, in: ALBUQUERQUE, José Augusto Gilhon (org.) Sessenta anos de política externa 1930-1990. São Paulo: Cultura Editores Associados/ Núcleo de Pesquisa em Relações Internacionais - USP, v. 3, 1996, p. 443 e 444. 
trazida pelo choque do petróleo ensejou nova orientação internacional da política externa, a qual refletia diretamente no encaminhamento da diplomacia para o Oriente Médio.

A realidade emergente proveniente da crise do petróleo exigiu respostas pragmáticas do governo brasileiro. A primeira dessas respostas foi o estabelecimento de missóes diplomáticas e a troca de embaixadores plenipotenciários entre Brasil e Arábia Saudita. Nesse contexto, em maio de 73, visitou o país o chanceler saudita Omar Sakkaf, tendo-se avistado com o presidente da República, o ministro das Relações Exteriores e outras autoridades políticas. Durante a visita, foi acertado o estabelecimento de relações diplomáticas plenas entre Brasil e Arábia Saudita. O primeiro representante brasileiro no Reino da Arábia Saudita foi o embaixador Murilo Gurgel Valente. Em 74, a Arábia Saudita, por sua vez, enviou seu representante junto ao governo brasileiro, o embaixador Mamoun K. Kabbani.

O chanceler saudita retornaria novamente ao Brasil, em setembro de 74, para a criação da Comissão Mista Brasil-Arábia Saudita, destinada a criar "uma estrutura para o desenvolvimento da cooperação bilateral". ${ }^{6} \mathrm{Na}$ ocasião, o chanceler manteve contato com diversas autoridades brasileiras, entre as quais os ministros das Relações Exteriores, da Indústria e Comércio, das Minas e Energia e o secretário do Planejamento da República. A visita ensejou a assinatura de Declaração Conjunta salientando a oportunidade para reestudarse as relaçóes bilaterais e os problemas internacionais da época, mormente a questão palestina.

A Declaração Conjunta, embutida da retórica comum a esse tipo de documento, registrava também a necessidade de ação solidária em prol da paz e do desenvolvimento, com ênfase na criação de nova ordem econômica internacional com maiores benefícios para os países em desenvolvimento. Todavia, o ápice da visita deu-se com a criação da referida Comissão Mista (Joint Committee) para tratar de questóes consideradas prioritárias, como o fornecimento de petróleo saudita ao Brasil e de bens de serviço para a Arábia Saudita, o intercâmbio tecnológico, a assistência técnica, a associação de capitais privados e públicos, a cooperação financeira e o intercâmbio cultural. $\mathrm{O}$ suprimento de petróleo era o tema o qual mais interessava ao Brasil em virtude da crise energética que enfrentava. Observava-se, dessa forma, no contexto internacional da época, a agenda econômica determinando a agenda política nas relações exteriores do país.

A visita do chanceler saudita rendeu também acordo de Cooperação Econômica e Técnica, com a finalidade de desenvolver a indústria de origem agrícola, manufatureira e de transportes aéreos e marítimos mediante o

\footnotetext{
${ }^{6}$ Relatório do MRE, 1974, p. 76.
} 
estabelecimento de companhias conjuntas ou mistas. Todavia, o estabelecimento de contatos e a assinatura de acordos entre os dois países, louvável do ponto de vista político, trouxe poucos resultados práticos, pois, embora tenha ocorrido aumento das trocas comerciais entre 68-78, a balança comercial permaneceu desfavorável ao Brasil na ordem de 900 milhões a 1,3 bilhões de dólares. Nesse contexto, a fim de fazer frente ao aumento vertiginoso das importações de petróleo da Arábia Saudita, o país decidiu intensificar as exportações de calçados, couros, laminados, compensados e chapas de madeira, vestuário, pisos, azulejos e louças sanitárias para aquele país. ${ }^{7}$

$\mathrm{O}$ aumento do comércio com a região ia ao encontro da necessidade de equilibrar as contas externas, nas quais o petróleo contribuía de maneira significativa para a existência do forte déficit comercial com os países árabes. Com efeito, em 71, após aproximações entre a Petrobras e a recém-nacionalizada Iraq Petroleum Company, ficou decidido que, em contrapartida ao montante de petróleo já comprado pela Petrobras, o Iraque passaria a adquirir semimanufaturados e manufaturados de produção nacional em igual ou superior valor ao do óleo iraquiano ${ }^{8}$. No mesmo ano, ocorreu a apresentação de credenciais do primeiro embaixador do Iraque no Brasil.

Ainda em relação ao Iraque, no contexto do choque de oferta e do déficit na balança comercial, o Brasil furou boicote internacional ${ }^{9}$ contra aquele país e autorizou a Petrobras, então presidida por Geisel, a comprar petróleo iraquiano. O gesto ampliou as relações com o Iraque, o qual passou a privilegiarnos como parceiro comercial, chegando a ser o maior marcado no exterior para serviços, automóveis, carne, frango e armamentos brasileiros ${ }^{10}$. Além disso, a

\footnotetext{
7 No ano de 79, o desequilíbrio comercial entre os dois países representava um bilhão de dólares desfavoravelmente ao Brasil, que importava 1,2 bilhōes de dólares em petróleo da Arábia Saudita. Em MAJZOUB, Ismail. "Os fatores geo-históricos", in: FUNAG. Relaçōes entre o Brasil e o Mundo Arabe: construção e perspectivas. Brasília: Funag, 2001, p. 66.

${ }^{8}$ Em 11 de maio de 71, Brasil e Iraque assinaram, em Bagdá, por ocasião da visita do chefe de Estado Maior das Forças Armadas do Brasil, acordo sobre Cooperação Comercial, pelo qual o Brasil comprometeuse a comprar petróleo do Iraque, cujo governo assumia a obrigação de facilitar a colocação, em seu mercado, de produtos brasileiros em valor correspondente à quantidade de petróleo adquirido. VIZENTINI, P. G. F., Op. cit., p. 182.

${ }^{9}$ O Iraque havia nacionalizado os ativos britânicos da Iraq Petroleum Company e o Brasil, desconsiderando o bloqueio imposto pela British Petroleum e por outras multinacionais do ramo, que impedia Bagdá de vender petróleo no exterior, tornou-se o primeiro comprador de óleo proveniente dos campos confiscados. A posição brasileira rendeu frutos políticos em 79 , quando o embaixador do Iraque, Zaid Haider, garantiu ao chanceler Saraiva Guerreiro que o país estava pronto para suprir as necessidades brasileiras de petróleo diante da escassez causada pela crise no Irã. Na mesma época, após encontro entre o chefe do departamento de material bélico e futuro ministro do Exército, General Walter Pires, com o chefe de Missão do Iraque, General Amin, veiculou-se a informação de que o Brasil venderia ao país, em troca de petróleo, U\$ 500 milhōes em material bélico. Cf. VIZENTINI, P. G. F., Op. cit., p. 253-254.

10 FLECHA DE LIMA, Paulo Tarso. "Diplomacia e Comércio: notas sobre a política externa brasileira nos anos 70" in: ALBUQUERQUE, José Augusto Gilhon (org.) Sessenta anos de política externa 19301990. São Paulo: Cultura Editores Associados/Núcleo de Pesquisa em Relaçôes Internacionais - USP, v. 2, 1996, p. 226 e 227.
} 
Braspetro $^{11}$, subsidiária da Petrobras, descobriu, em 77, em atividades no território iraquiano, o maior campo de petróleo naquele Estado. Tratava-se do campo de Majnoon ${ }^{12}$, com reservas superiores a 1 bilhão de metros cúbicos ${ }^{13}$, avaliadas em US\$ 10 bilhões e com o mais baixo custo de extração. Todavia, infelizmente, a companhia brasileira teve de abandoná-lo, em 79 , devido à guerra entre Irã e Iraque, quando este país pagou ao Brasil US\$ 300 milhões como indenização por gastos em pesquisas geológicas, além de assinar contrato de fornecimento de 150 mil barris/dia por 15 anos em condiçōes altamente favoráveis. ${ }^{14}$

Com relação a Israel, em janeiro de 72, o Brasil assinou convênio complementar ao Acordo Básico de Cooperação Técnica de 62, relativo à colaboração bilateral no campo da irrigação e da valorização de áreas atingidas pela seca no Nordeste. Em agosto do mesmo ano, visitou o país o ministro das Finanças de Israel, Pinhas Sapir, que manteve contatos com os ministros da Fazenda, das Relações Exteriores, do Comércio e da Indústria, e do Planejamento. Em março de 73, ficou acertada entre os dois países a vinda de técnicos israelenses para a instrução de pilotos e técnicos brasileiros na utilização dos 16 caças Mirage da Força Aérea Brasileira. O Brasil esperava adquirir a experiência alcançada por Israel na utilização dos caças supersônicos durante as guerras com os árabes. Nesse sentido, a orientação deveria ser dada em termos de estágios, em Israel, para pilotos brasileiros e informaçôes sobre adaptações que eventualmente poderiam ser feitas de modo a obter-se outro rendimento dos avióes, além da assistência na parte de manutenção. ${ }^{15}$

\section{Linhas gerais do governo Geisel}

A política externa do presidente Geisel é, sem dúvidas, a mais estudada entre a bibliografia disponível, quiçá por ter sido a mais ousada entre os governos militares. Com efeito, a ênfase na identificação ideológica com o bloco político-

\footnotetext{
${ }^{11}$ A Braspetro atuava na prospecção e na extração de jazidas de hidrocarbonetos no exterior, e, por meio de uma de suas divisões, a qual se transformaria, mais tarde, na Interbras, dedicava-se ao comércio exterior de bens e serviços.

${ }^{12}$ A Braspetro assinara contrato de risco com a Iraq Petroleum Company para a exploração de petróleo nas áreas de Majnoon e Nahr Umr em 72. O contrato, muito criticado à época, trouxe resultados muito favoráveis aos interesses brasileiros, mormente com a renegociação de seus termos, a pedido de Bagdá, em 79. A Braspetro passou de concessionária a operadora dos campos de Majnoon, ressarcindo-se de todos os gastos incorridos não em moeda, mas em petróleo; sendo que o preço do barril foi calculado em nível ligeiramente inferior ao de mercado, o que também favoreceu o lado brasileiro. Em 80, a eclosão da guerra entre Iraque e Irã transformou a região de Majnoon em teatro de operaçôes bélicas nos oito anos subseqüentes. Diante de tal fato, não poderia ter sido mais bem avisada, para o Brasil, a renegociação das condiçôes contratuais. O êxito da empresa na pesquisa de petróleo em países árabes contribuiu significativamente para consolidar as relações bilaterais do Brasil com a região. ROSA, Luciano Ozório, Op. cit., p. 446 e 447.

13 WANG, Ana Beatriz Gaertner Marabuto. Dilema energético e politica exterior (os). Dissertação de Mestrado. Brasília: Universidade de Brasília, 2003, p. 123.

14 BANDEIRA, Muniz. As Relaçôes Perigosas: Brasil e Estados Unidos (de Collor a Lula). Rio de Janeiro: Editora Civilização Brasileira, 2004, p. 59.

15 VIZENTINI, P. G. F., Op. cit., p. 184.
} 
militar ocidental, a qual caracterizou o governo Castelo Branco e que foi atenuada significativamente durante a gestão Costa e Silva, cedeu lugar à orientação mais pragmática com Geisel. A nova linha de atuação diplomática passou a rejeitar alinhamentos automáticos e apriorísticos com o Mundo Ocidental, com cujos valores declarava, entretanto, seguir identificando-se. A multilateralização e a mundialização da política externa foram reafirmados novamente durante o "Pragmatismo Ecumênico e Responsável” do governo Geisel.

O termo "pragmatismo", muito utilizado durante o período, surgiu, pela primeira vez, em 19 de março de 74, no discurso de Geisel durante a primeira reunião presidencial em Brasília. Designava a política externa pragmática e "responsável dos Deveres da Nação", com atenção especial "ao nosso relacionamento com as nações-irmãs da circunvizinhança de aquém e alémmar". ${ }^{16} \mathrm{Na}$ concepção do presidente, o "pragmatismo responsável", conforme aponta Vizentini ${ }^{17}$, consubstanciava-se em política externa que repudiava discussões semânticas, bem como o alinhamento com os extremos da lógica bipolar da Guerra Fria.

De acordo com o chanceler Azeredo da Silveira ${ }^{18}$, a política externa era "pragmática" porque se opunha "ao apriorismo e ao idealismo verbal". Baseavase na "apuração realista dos fatos e na avaliação ponderada das circunstâncias", visando, dessa forma, "à eficiência material e não à coerência formal, na consecução dos objetivos nacionais". O termo "responsável” buscava evitar que o pragmatismo fosse qualificado de oportunista, tornando o conceito mais palatável às cúpulas militares e aos setores mais conservadores da sociedade. Já o qualificativo "ecumênico", cunhando pelo próprio chanceler, descrevia o caráter universal da política externa, a qual deveria olhar para todas as direções no sentido de expandir as relações internacionais do país. Nesse sentido, a política externa demonstrava-se ousada e livre para expandir-se de forma indiferenciada a todos os países.

O caráter "ecumênico" da atuação diplomática brasileira sempre foi um dos pontos salientes do discurso político do governo Geisel. A nova posição não se coadunava com a exclusão apriorística de determinados países do âmbito da atuação da diplomacia. A idéia de política externa "ecumênica" traduziu-se, pois, no esforço deliberado para preencher os vazios diplomáticos da atuação brasileira, sem preconceitos ideológicos e à luz dos interesses nacionais. Nesse sentido, a crise do petróleo trouxe a atenção da chancelaria para um dos mais evidentes exemplos desses vazios diplomáticos: o Oriente Médio.

16 BRASIL/MRE. Resenha de política exterior do Brasil. Brasília: Departamento de Comunicação e Documentação do MRE, ano I, nº. I, 1974, p. 9.

17 VIZENTINI, P. G. F., Op. cit., p. 205.

${ }^{18}$ Em Aula-de-Mestre, proferida pelo chanceler Azeredo da Silveira, na Faculdade de Direito da Universidade Federal de Pernambuco, em 4 de março de 75. BRASIL/MRE. Resenha de politica exterior do Brasil. Brasília: Departamento de Comunicação e Documentação do MRE, ano II, nº. IV, 1975, p. 39-40. 
Durante a elaboração da política do "Pragmatismo Responsável”, o Brasil estava inserido no contexto internacional da Guerra Fria, vivendo sob a hegemonia de uma das duas superpotências e, destarte, com limites à suas iniciativas diplomáticas. Logo, uma das maneiras de ampliar a autonomia do país consistia em afastar-se do campo hegemônico estadunidense por meio da universalização da política externa, isto é, da multiplicação dos contatos internacionais. Com efeito, pode-se dizer que, se a política externa independente nasceu de um projeto político, de uma concepção intelectual, o "Pragmatismo Responsável e Ecumênico" foi a tentativa de superar uma história que começou em 64, tirando o Brasil da lógica do conflito Leste-Oeste para inseri-lo no contexto dos interesses nacionais, os quais demandavam a revisão da atuação diplomática. Sobre o assunto, diria o chanceler Silveira, em 74, na Escola Superior do Exército que

... num mundo em constante mutação, não há coincidências permanentes nem divergências perenes. Nessas condiçōes, não pode haver alinhamentos automáticos, porque o objeto da ação diplomática não são países, mas situações. O que devemos buscar em cada momento é explorar as faixas de coincidência que temos em cada um dos países, procurando ao mesmo tempo reduzir as áreas de divergência ou de confrontação. Essa atitude pragmática é a essência mesmo da atividade diplomática. ${ }^{19}$

A diplomacia do chanceler Azeredo da Silveira buscou o direito de formular posições independentes para o país, sem a preocupação em satisfazer as pressões das superpotências. Logo, tornava-se imprescindível a universalização de contatos da política externa, o que, por sua vez, implicava mudanças importantes nas posições com o mundo árabe, haja vista a perspectiva de aproximação concreta com os países do Oriente Médio. O discurso de posse do chanceler Azeredo da Silveira ${ }^{20}$, em 15 de março de 74 , já anunciava as diretrizes do universalismo da política externa ao afirmar que "não será possível ao Brasil alhear-se do que ocorre em outras áreas, do que emerge como novas potências na África, no Oriente Próximo, na Ásia e na Europa”. De acordo com o presidente Geisel ${ }^{21}$, por sua vez, a diplomacia deveria estar sempre alerta para a detecção de novas oportunidades, bem como atuar em serviço "dos interesses de nosso comércio exterior, da garantia do suprimento adequado de matériasprimas e produtos essenciais e do acesso à tecnologia mais atualizada de que não dispomos ainda, fazendo para tanto, com prudência e tato, mas com firmeza, as opçōes e realinhamentos indispensáveis".

${ }^{19}$ Apud FONSECA, Gelson Jr. A legitimidade e outras questões internacionais. São Paulo: Paz e Terra, 1998 , p. 321.

${ }^{20}$ BRASIL/MRE. Resenha de politica exterior do Brasil. Brasília: Departamento de comunicação e documentação do MRE, ano I, nº. I, 1974, p. 21.

${ }^{21}$ Discurso do presidente Geisel na primeira reunião ministerial realizada no Palácio do Planalto, em 19 de novembro de 1974. Idem, p. 9. 
No contexto do Oriente Médio, foi o pragmatismo de Geisel que intensificou a "Diplomacia do Interesse Nacional" de seu antecessor, tendo em vista impulsionar o projeto desenvolvimentista e a política de posições equilibradas para a região. A principal meta da política externa para com os países árabes, durante a gestão do chanceler Azeredo da Silveira, foi o aumento da exportação de produtos brasileiros, baseada nas idéias do ministro Delfim Neto de que era preciso exportar para poder importar. Nesse contexto, o Itamaraty deu tal importância ao tema que não só desmembrou o Departamento de Oriente Próximo, Ásia e Oceania - de forma a criar interlocutores que correspondessem à expectativa governamental de crescimento do comércio com os países árabes - como também criou o Departamento de Promoção Comercial para impulsionar as exportaçōes brasileiras.

\section{O governo Geisel frente ao primeiro choque do petróleo}

O governo Geisel deparou-se, de início, com a crise do petróleo, a qual incidiu fortemente na balança comercial brasileira, uma vez que o país importava óleo cru na proporção de $80 \%$ de suas necessidades de consumo. O presidente Geisel, que aspirava a conduzir o Brasil à última etapa do desenvolvimento econômico, havia apostado todas as fichas no plano de desenvolvimento elaborado pelo ministro do Planejamento, Reis Velloso, orientado para grandes inversões em infra-estrutura e para avançada integração industrial. Dessa forma, o projeto de desenvolvimento dependia sobremaneira do óleo importado e de capitais externos.

O "Pragmatismo Responsável" tinha efetivamente conteúdo operacional, o qual procurava adequar as demandas de uma economia que havia avançado substancialmente na industrialização; entretanto, apresentava ainda inúmeros pontos de vulnerabilidade, os quais se mostraram particularmente agudos no contexto das turbulências provocadas pela crise do petróleo. Assim, fazia-se necessário a construção de relações prioritárias com determinados países e regiōes por meio de aproximaçôes políticas, pela oportunidade de grandes projetos comuns ou pela penetração comercial. A partir dessas diretrizes, foi implementada a visão do Oriente Médio como parceiro estratégico ${ }^{22}$. Nesse sentido, o Brasil buscou cooperação regional com países como Argélia, Líbia, Iraque e Arábia Saudita, sob a forma de joint-ventures para a prospecção de

\footnotetext{
$22 \mathrm{O}$ conceito de parcerias estratégicas, de acordo com Lessa, diz respeito às "relaçôes políticas e econômicas prioritárias reciprocamente renumeradoras, constituídas a partir de um patrimônio de relações bilaterais universalmente configurado". A construção de parcerias estratégicas é "fruto da compatibilização da vocação histórica do Brasil para a universalidade com a necessidade de aproximaçóes seletivas, o que abre a possibilidade para movimentos de adaptação aos nichos de oportunidade e aos constrangimentos internacionais que se apresentam conjunturalmente". LESSA, Antônio Carlos. "A diplomacia universalista do Brasil: a construção do sistema contemporâneo de relações internacionais" Revista Brasileira de Política Internacional. Brasília, Edição Especial 40 anos, 1998, p. 31.
} 
petróleo por meio da Braspero e para o desenvolvimento tecnológico e indutrialmilitar (venda de armas brasileiras e projetos comuns no campo de mísseis).

De acordo com Lessa ${ }^{23}$, a ação internacional do governo Geisel pautou-se pelo objetivo claro de "perseguir os elementos necessários para a consecução do projeto de desenvolvimento, então esboçado nas linhas do II Plano Nacional de Desenvolvimento", lançado por Geisel, em setembro de $74 .{ }^{24} \mathrm{O}$ plano, longe de adotar estratégia defensiva, preparou o aprofundamento do processo de industrialização por substituição de importações, com vistas a tornar o país auto-suficiente em insumos básicos e, se possível, em energia. Nesse sentido, o governo Geisel buscou a revisão da agenda de relações bilaterais por meio da consecução de estratégia de diversificação dos vínculos externos do país.

$\mathrm{O}$ processo de universalização da política externa de Geisel tornou necessário, em um primeiro momento, rever os denominados "relacionamentos excludentes", definidos por Lessa ${ }^{25}$ como "o conjunto de relações bilaterais e apoios políticos explícitos ou velados que impediam o país de obter a ampliação de mercados e o acesso a insumos importantes para o projeto de desenvolvimento em via de implementação". Assim, logo tratou de libertar o país das limitações impostas pela associação ao colonialismo português e ao separatismo sul-africano, que obstruíam o acesso às ex-colônias africanas recémindependentes; à eqüidistância favorável, na prática, à Israel, a qual impedia o adensamento de relaçôes com o mundo árabe; e, por fim, à China nacionalista, que privava o país do intercâmbio com a China continental. A nova política, conforme aponta Vizentini ${ }^{26}$, baseava-se na "análise pragmática da conjuntura energética do momento", tendo ainda fundamento ideológico nas teses de Araújo Castro, para quem a política de aproximação com a região fazia parte do Plano Nacional de Desenvolvimento do país.

O discurso diplomático brasileiro a partir do governo Geisel passou a centralizar a questão palestina em relação ao conflito no Oriente Médio. Com efeito, o impacto da nova política para o Oriente Médio atingiu seu ápice com

\footnotetext{
${ }^{23}$ LESSA, Antônio Carlos. "A estratégia de diversificação das parcerias no contexto do nacionaldesenvolvimentismo (1974-1979)". Revista Brasileira de Politica Internacional. Brasília, v. 38(1), 1995 , p. 24.

${ }^{24}$ O II PND tinha por metas principais: 1) o crescimento econômico médio de $10 \%$ ao ano, sem a ocorrência de superaquecimento da economia; 2) controlar a inflação; 3) manter equilíbrio razoável do balanço de pagamentos, mediante o aumento das exportaçóes em 150\% ao final do período 1975-1979, resultante da ampliação dos mercados consumidores no exterior; 4) promover o crescimento industrial do país com ênfase na indústria de equipamentos (bens de capital e eletrônica pesada) e no setor de insumos básicos, visando à substituição de importações; e 5) buscar a autonomia energética - mediante a intensificação da pesquisa do petróleo, a exploração do xisto, a substituição da gasolina por álcool como combustível, a constituição de sólido programa nuclear e a ampliação do setor hidroelétrico - ou a minimização da dependência em relação a fontes externas de energia. $C f$. WANG, Ana Beatriz Gaertner Marabuto, Op. cit., p. 53.

${ }^{25}$ LESSA, Antônio Carlos. "Israel e o mundo árabe...", Op. cit., p. 162.

26 VIZENTINI, P. G. F., Op. cit., p. 246.
} 
o encaminhamento, em 10 de novembro de 75, pelo embaixador Sérgio Correia da Costa, Chefe da Delegação do Brasil nas Nações Unidas, do voto a favor do projeto de resolução da Assembléia Geral que declarava o sionismo uma forma de racismo e de discriminação racial, considerando-o historicamente esgotado. A repercussão do voto brasileiro foi bastante mais negativa do que se esperava. À época, cogitou-se inclusive que o voto visava a angariar a simpatia dos Estados árabes de modo a patrocinar a venda de armas de produção nacional àqueles países, versão que foi desmentida pelo presidente Geisel. ${ }^{27}$

$O$ voto brasileiro, criticado no âmbito doméstico e internacional, demonstrou o rompimento da eqüidistância em detrimento de Israel e surpreendeu tanto a opinião pública quanto diplomatas e altos oficias do Exército. Para Lessa ${ }^{28}$, “o voto anti-sionista na ONU é o símbolo de um processo importante na construção do universalismo brasileiro", no sentido de que demonstrava que as relações internacionais do país não estavam adstritas ao ocidentalismo radical e a ligações estreitas com as orientações de política internacional dos Estados Unidos.

A crise do petróleo, bem como a evolução do diálogo Norte-Sul e da Guerra Fria, conduziram a diplomacia brasileira a aproximar-se, nos foros internacionais, da maioria dos países em desenvolvimento, grupo que inclui praticamente todos os Estados do Oriente Médio. A região tornava-se, de fato, nova e importante área de interesse para o Brasil. Para Vizentini ${ }^{29}$, "não se tratava apenas de garantir as importaçóes de petróleo e aceder a um amplo mercado consumidor de produtos agrícolas, manufaturas, serviços e armamentos. (...) Tratava-se do esboço de um eixo de cooperação entre potências médias emergentes do Terceiro Mundo".

\section{Incremento prático das relações com a região durante o período}

$\mathrm{O}$ ano de 74 testemunhou notável incremento na expansão da presença do Brasil nos países árabes tanto no plano político quanto no econômico. Com efeito, em junho daquele ano, foram abertas embaixadas nos Emirados Árabes Unidos e em Bahrein. Em julho, foram estabelecidas relações diplomáticas com o Sultanato de Omã e, mais tarde, com mais dez Estados da região, dando início à intensa temporada de troca de visitas de alto nível, haja vista a esperança de criarem-se novos mercados para as exportações nacionais. ${ }^{30} \mathrm{Em}$ 78, foi firmado, no exterior, o maior contrato assinado por empresa brasileira. Tratava-se do contrato para a construção de estrada de ferro ligando Bagdá a Akashat, firmado entre o Consórcio Mendes Júnior-Interbrás e o Ministério

\footnotetext{
27 BREDA DOS SANTOS, Norma. "As posições brasileiras...", Op. cit., p. 12.

28 LESSA, Antônio Carlos. "Israel e o mundo árabe...”, Op. cit., p. 168.

29 VIZENTINI, P. G. F., Op. cit., p. 12.

30 LESSA, Antônio Carlos. "Israel e o mundo árabe...”, Op. cit., p. 169.
} 
dos Transportes do Iraque. ${ }^{31}$ No que diz respeito à exportação de bens, este país passou a importar do Brasil grandes quantidades de veículos automotores, frangos congelados e açúcar. ${ }^{32}$ Além disso, a Braspero deu continuidade à prospecção e à extração de petróleo na região de Bassora, naquele país.

A crise do petróleo contribuiu sobremaneira para a intensificação das relações com o Oriente Médio. Com a crescente demanda doméstica, o Brasil passara a comprar da região mais de $80 \%$ do petróleo consumido internamente, o que gerava grande déficit comercial. Em 73, o saldo negativo na balança comercial com os países árabes era de US\$ 353 milhōes. Em 74, o valor passou para US $\$ 1,759$ bilhões e, em 78 , para 3,314 bilhões. ${ }^{33} \mathrm{Na}$ tentativa de equilibrar o problema da balança de pagamentos, o país passou a exportar quantidades crescentes de manufaturados para a regiáo, produzidos principalmente pela Embraer e pela fábrica de material bélico Imbel ${ }^{34}$. Apesar do esforço do Itamaraty de levar a cabo política de promoção de exportações para os países árabes ${ }^{35}$, a balança comercial com a região foi sempre fortemente deficitária, devido à grande quantidade de petróleo importada. Nesse contexto, além do Iraque, surgiram como principais fornecedores desse insumo Arábia Saudita, Kuwait e Irã.

De modo a atenuar os saldos negativos, o Brasil procurou, durante toda década de 1970, aumentar suas vendas ao Oriente Médio e receber investimentos externos em petrodólares. Dessa forma, fortaleceu os laços diplomáticos e comerciais com a região e tomou diversas iniciativas, firmando acordos com países como Kuwait, Arábia Saudita, Irã e Iraque. Tais acordos previam a compra de petróleo e a venda de manufaturas brasileiras. Nesse contexto, em 74, a Petrobras já desenvolvia amplo programa de pesquisa na área petrolífera no Egito, Irã, Líbia, Iraque, Kuwait e Arábia Saudita, tendo em vista a importação de petróleo com prazos dilatados de pagamento junto às empresas estatais árabes. ${ }^{36}$

O Iraque - Estado com o qual o Brasil, a partir de 74, manteve vínculos diplomáticos estreitos - mostrou-se o maior exportador de petróleo para o

\footnotetext{
31 VIZENTINI, P. G. F., Op. cit., p. 249.

32 Relatório do MRE, 1978, p. 66.

33 SILVA, Heloisa Conceição Machado. Da substituição de importações a substituição de exportações: $A$ politica de comercio exterior brasileira de 1945-1979. Tese de Doutorado. Brasília: Universidade de Brasília, 2003, p. 583.

${ }^{34} \mathrm{Em}$ contexto no qual os países árabes receavam o comunismo, estavam em conflito com os Estados Unidos, por causa de Israel, e ressentiam-se das potências industriais da Europa Ocidental, notadamente a Inglaterra e a França, das quais foram colônias, o Brasil, como potência capitalista emergente, apresentavase em condições de fornecer-lhes todo o tipo de mercadorias de que necessitassem, inclusive armamentos. 35 Convém ressaltar que, durante o governo Médici, foi criado o Departamento de Promoção Comercial pelo então conselheiro Paulo Tarso Flecha de Lima, visando a modernizar o setor comercial do Ministério das Relações Exteriores. Durante o governo Geisel, o Itamaraty, por meio do Departamento de Promoção Comercial, assumiu a política de incremento das exportações para o Oriente Médio.

36 SILVA, Heloisa Conceição Machado da, Op. cit., p. 583.
} 
país no período 74-79. Com efeito, em agosto de 75, o Brasil chegou a importar 930 mil barris/dia da estatal iraquiana Iraq National Oil Company. De modo a contrabalançar o comércio com aquele país, exportou bens industrializados tais como veículos Volkswagen, caminhões, peças e eletrodomésticos, além de minério de ferro, óxido de alumínio, madeira, carnes congeladas e serviços, com destaque para a participação de empresas de construção em projetos de infra-estrutura no Iraque ${ }^{37}$.

Em 75, o Itamaraty organizou a participação do Brasil nas feiras internacionais de Trípoli, Teerã, Argel, Bagdá e Casablanca. Igualmente sob o patrocínio do ministério, realizou-se a II Exposição Industrial Brasileira no Kuwait. Algumas dessas participações incluíram mostras representativas de produtos industriais nacionais de médio e grande porte. ${ }^{38} \mathrm{Em} 76$, o país participou das feiras internacionais de Trípoli, Teerã, Argel, Bagdá e Damasco e realizou a primeira exposição industrial brasileira na Arábia Saudita. ${ }^{39}$ No mesmo ano, a fim de dinamizar as relações comerciais com os países árabes, a Interbras inaugurou um escritório central para o Oriente Médio, enquanto que técnicos enviados pela Petrobras à região negociaram a extensão dos prazos de pagamento junto às principais empresas fornecedoras de petróleo. Em 77, o país voltou a participar de várias feiras de promoção de exportações no intuito de diminuir o déficit comercial com a região, mantendo presença nas feiras internacionais de Trípoli, Teerã, Argel, Bagdá e Cairo. Além disso, foram organizadas exposição industrial brasileira no Kuwait e exposição tecnológica na Arábia Saudita no mesmo ano. ${ }^{40}$

\section{Linhas gerais do governo Figueiredo}

Não obstante o contexto interno e externo consideravelmente desfavorável ${ }^{41}$, o governo Figueiredo pautou-se por política externa de continuidade em relação ao "Pragmatismo Responsável" de seu antecessor. A presença da diplomacia brasileira em todas as áreas do planeta foi conservada e intensificada pelo chamado "Universalismo" da gestão do chanceler Saraiva Guerreiro, que tentou conservar a margem de autonomia internacional adquirida pela política externa

\footnotetext{
37 De acordo com Sato, o Brasil praticou verdadeiro mecanismo de "countertrade" - uma versão moderna e sofisticada de escambo - com os países do Oriente Médio, mormente com o Iraque, o que explicava o grande aumento na compra de petróleo da região (muitas vezes trocados diretamente por automóveis e outros produtos exportados pelo Brasil). Cf. SATO, E. "40 Anos de Política Externa Brasileira, 19581998: Três Inflexōes”. Revista Brasileira de Politica Internacional. Brasília, Edição Especial 40 anos, 1998 , p. 21.

38 Relatório do MRE, 1975, p. 121.

39 Relatório do MRE, 1976, p. 83.

40 Relatório do MRE, 1977, p. 78.

41 Crise econômica interna, com queda do crescimento, endividamento externo e inflação altos. No contexto externo, o aumento das taxas de juro pelos Estados Unidos fazia piorar a situação de países altamente endividados, como era o caso do Brasil.
} 
dos governos anteriores. O Itamaraty buscou aumentar a cooperação com os países do Sul, a qual poderia reforçar o poder de barganha em negociações econômicas multilaterais. Nesse contexto, os Estados do Oriente Médio passaram a ser vistos como fundamentais para o tipo de inserção internacional que o país buscava, por encaixaram-se nos projetos de cooperação Sul-Sul ambicionados pela chancelaria.

Logo de início, o novo governo teve que enfrentar o segundo choque do petróleo, em 79, quando o Brasil foi obrigado a contrair empréstimos junto ao Fundo Monetário Internacional, de modo a fazer frente às dívidas contraídas durante o "milagre econômico" e aumentadas, posteriormente, com a elevação dos juros internacionais. As dívidas aumentavam na medida em que as políticas nacionais não contribuíam para aliviar o crônico déficit na balança comercial. Embora o montante da exportação agrícola tivesse sido ampliado, ainda não era suficiente para cobrir o déficit. Além disso, o empresariado nacional também não se mostrava preparado para abrir frente exportadora expressiva para os países árabes, conforme as expectativas do governo federal.

A inexperiência foi a principal causa para a exportação de produtos manufaturados aquém do esperado pelo governo. O despreparo dos exportadores para perceberem as sutilezas que envolviam o mercado árabe $\mathrm{e}$ toda sua dimensão cultural e os pesados entraves burocráticos que envolviam o comércio exterior no Brasil refletem algumas das razões para o aumento pouco significativo do comércio com os países do Oriente Médio. Com efeito, a região da Ásia e do Oriente Médio passou de uma participação relativa, como destino das exportações brasileiras, de 3,46\%, em 71, para 9,86\%, em $81^{42}$.

Ainda assim, no que se refere à crise do petróleo, o ex-chanceler Saraiva Guerreira $^{43}$ lembra que "poucos países fizeram tanto para reduzir sua dependência do petróleo com o Brasil, quer aumentando sua produção na plataforma, a grandes profundidades, quer lançando o pró-álcool”. Nesse sentido, a redução dos gastos com petróleo de US\$ 28,3 bilhōes, em 84, para 12 bilhōes, em 86, deveu-se graças à infra-estrutura de substituição e ao aumento da produção nacional de petróleo, executada com capitais estrangeiros. ${ }^{44}$

A realidade era que, com a nova crise, com efeitos rapidamente detectados pelo país, o Itamaraty pouco pôde fazer para contornar o problema, uma vez que a condução das negociações da dívida externa, outrora responsabilidade da chancelaria, passaram para o Ministério da Fazenda. Nesse contexto, as questôes de política externa foram preteridas em função da agenda econômica,

42 FLECHA DE LIMA, Paulo Tarso, Op. cit., p. 236.

43 GUERREIRO, Ramiro Saraiva. Lembranças de um empregado do Itamaraty. São Paulo: Siciliano, 1992, p. 176.

${ }^{44}$ Conforme aponta Silvana Silva, no caso em tela, "houve, portanto, uma substituição da dependência energética pela financeira". Cf. SILVA, Silvana Romancini. A politica externa brasileira para os países árabes de 1974 a 1984. Brasília: Dissertação de mestrado, 1988, p. 58. 
que se sobrepunha à diplomática. Os acordos, os contratos e as renegociações da dívida externa minaram a presença de outros temas importantes da agenda externa do país.

Felizmente, a crise de 79 não teve a intensidade e a duração da crise de 73. Diversos fatores concorreram para a conjuntura internacional diferente, tais como o excedente de petróleo acumulado por causa da alta dos preços, a utilização de fontes de energia alternativas e a queda no consumo desse insumo, devido à desaceleração do ritmo da atividade econômica mundial. Entretanto, esses elementos não minimizaram a crise brasileira, provocada pelo amplo endividamento externo. A crise mundial era apontada pelo Executivo como a principal causa da crise econômica doméstica.

\section{O governo Figueiredo frente ao segundo choque do petróleo}

A situação econômica e política mundial tornou-se mais adversa para o Brasil com o segundo choque do petróleo, causado pela Revolução no Irã e pela primeira Guerra do Golfo. Com o advento do conflito entre Iraque e Irã, novo foco de instabilidade política foi criado no Oriente Médio, gerando nova crise mundial e conseqüente elevação da cotação internacional do barril de petróleo. A nova crise produziu repercussão imediata no Brasil, onde as reservas de petróleo estavam em declínio. O principal medo com o início da guerra era a interrupção do fornecimento externo, uma vez que o Iraque respondia por metade de nossas importaçôes e, agora, encontrava-se em guerra.

Todavia, graças ao relacionamento especial com o Iraque ${ }^{45}$, do qual o embaixador Paulo Tarso de Flecha Lima fora o artífice, o Brasil enfrentou os dois choques do petróleo sem necessidade de fazer racionamento, quando o preço do barril desse insumo saltou de US\$3,00 para US\$12,00, entre outubro de 73 e dezembro de 74, e, posteriormente, quando alcançou US\$36,00 entre 81 e 83. Em 79, quando eclodiu a crise política no Irã, o embaixador do Iraque em Brasília, Zaid Haidas, anunciou que seu país estava pronto para preencher a lacuna de fornecimento deixada pelo Irã - responsável pelo suprimento de $25 \%$ da demanda de petróleo no país -, em reconhecimento ao fato de o Brasil ter sido o primeiro Estado, em 71, a quebrar o boicote ao óleo iraquiano após a nacionalização das empresas pretolíferas naquele país. ${ }^{46}$

A culpa pela não-diversificação dos fornecedores de petróleo foi atribuída à Petrobras, a qual perseguia política de adquirir petróleo exclusivamente pelos

\footnotetext{
45 Com efeito, o Iraque tornara-se grande parceiro comercial do Brasil, de onde importava material bélico (carros de combate da Engesa e foguetes da Avibrás) no valor de mais de US\$ 500 milhōes, 175 mil automóveis (Passat, da Volkswagen), café, frango, óleo vegetal e outros produtos. Ver BANDEIRA, Muniz, Op. cit., p. 59.

46 WANG, Ana Beatriz Gaertner Marabuto, Op. cit., p. 123.
} 
preços mais baixos, em lugar de diversificar os fornecedores. Todavia, a estratégia da estatal brasileira não pode ser totalmente criticada, uma vez que a opção por importar óleo de outros países, como, por exemplo, Equador, México e Venezuela, sairia bem mais cara, onerando, assim, ainda mais o grande déficit no balanço de pagamentos, o que punha em risco o projeto desenvolvimentista do regime militar. Com efeito, em 79, Iraque, Arábia Saudita e Irã ainda eram responsáveis pelo fornecimento de aproximadamente $80 \%$ do petróleo importado pelo país. ${ }^{47}$

A essa realidade acresce-se o malogro do objetivo do Brasil de equilibrar o comércio com o Oriente Médio, de modo a contra-balancear o déficit comercial com a região. Os dados a respeito do aumento das exportações para o Oriente Médio indicam que estas saltaram de $1 \%$ do total exportado, no período de 67 a 72 , para 3\%, entre 73 e 78 , e para $6 \%$ entre 80 e 85 . No sentido inverso, as importações evoluíram de $6 \%$ do total, entre 67 e 72 , para $22 \%$ entre 73 e 78, recuando, mais tarde, para $14 \%$ entre 80 e 85 . A expectativa de atrair investimentos diretos dos países daquela região também foi frustrada, não obstante o fato de as petromonarquias estarem altamente capitalizadas à época, devido à alta do preço do petróleo. Os números apontam que, durante $67 \mathrm{e}$ 94, apenas $8 \%$ dos investimentos externos diretos registrados no Brasil vieram daqueles países. ${ }^{48}$

Um dos poucos resultados concretos de atração de capitais oriundos dos petrodólares foi o empréstimo concedido pela Arábia Saudita ao Brasil, no valor de US\$ 54 milhões, para o projeto hidroelétrico do Vale do São Francisco. ${ }^{49}$ No fim, os árabes preferiram o retorno rápido e seguro do investimento dos petrodólares na Europa e nos Estados Unidos.

\section{O malogro do incremento das relações comerciais com a região}

As primeiras tentativas de ingresso no mercado árabe foram frustradas. O próprio chanceler Saraiva Guerreiro ${ }^{50}$ reconhece que os resultados da corrida brasileira para obter investimentos e/ou oportunidades de financiamento e incremento do comércio de bens e de serviços nos Estados que estavam acumulando reservas de petrodólares foram "mofinos". Além disso, reforça a conclusão de que quem acabou ganhando foram os países centrais. Nesse sentido, resume ao dizer que "tirando alguns contratos de prestação de serviços com firmas brasileiras, de construção principalmente, pouca coisa se concretizou”.

\footnotetext{
47 Idem, p. 170.

48 Cf. LESSA, Antônio Carlos. "Israel e o mundo árabe...”, Op. cit., p. 171-172.

49 Relatório do MRE, 1977, p. 78.

50 GUERREIRO, Ramiro Saraiva, Op. cit., p. 178.
} 
As desculpas para o malogro da política de incremento de exportações para o Oriente Médio, na opinião do próprio Itamaraty, à época, advinham da falta de agressividade dos empresários brasileiros para competir com os países desenvolvidos na oferta de produtos e possibilidades de investimentos. O empresariado nacional, por sua vez, queixava-se do excesso de burocracia da chancelaria e da falta de flexibilidade dos setores governamentais.

Para Silvana Silva ${ }^{51}$, o esforço para preencher os mercados dos países árabes com produtos brasileiros chegou "atrasado", impedindo, dessa forma, que o país ocupasse mais espaço dentro do mundo árabe. A autora aponta a falta de especialistas no Oriente Médio e a falta de respostas rápidas da burocracia como os principais motivos do insucesso na região. Salienta também para a falta de empenho do empresariado nacional, "uma vez que ele não teve tempo para se preparar para competir num mercado desconhecido e com características bem peculiares, como, por exemplo, a restrição a certos produtos por questôes religiosas". Na opinião de Lessa ${ }^{52}$, que corrobora a versão da autora, "os esforços do Brasil para penetrar o Oriente Médio foram, sem dúvida, tardios e apressados, determinados que foram pela crise no fornecimento de petróleo".

Todavia, se os resultados econômicos com a região deixaram a desejar, no plano diplomático, por sua vez, os avanços foram consideráveis, haja vista o estreitamento de laços políticos com praticamente todos os países do Oriente Médio. Apesar de a chancelaria não ter atingido o objetivo em relação aos países árabes, o esforço feito nesse sentido proporcionou o estabelecimento de bases tanto diplomáticas quanto comerciais que permitiram a retomada dos mecanismos de dinamização das relações bilaterais com a região.

Por fim, apesar de os resultados alcançados ficarem aquém do esperado pelo governo, o Itamaraty desempenhou papel essencial na iniciativa nacional de tentar incrementar e diversificar o comércio com os países árabes após o primeiro choque do petróleo. Não obstante a promoção dos produtos nacionais nas principais feiras comerciais árabes - mormente no Iraque, na Líbia e na Arábia Saudita - procurando realçar a produção industrial brasileira, o ministério também sofreu mudanças internas, de modo a acomodar as novas demandas que a política externa criava. Com efeito, o desmembramento do Departamento de Oriente Próximo, Ásia e Oceania e a criação do Departamento de Promoção Comercial enfatizavam a busca por interlocutores que pudessem corresponder à expectativa governamental de incrementar o comércio com os países árabes.

51 SILVA, Silvana Romancini, Op. cit., p. 57-59.

52 LESSA, Antônio Carlos. "Israel e o mundo árabe...", Op. cit., p. 165. 


\section{Conclusão}

A política externa aplicada aos países árabes inseriu-se no conteúdo do programa pragmático segundo o qual o relacionamento diplomático deveria ser intensificado na medida em que crescia a sangria de divisas com a importação de petróleo. Dessa forma, embora o pragmatismo pretendesse redimensionar a política externa de forma duradoura e profunda - por meio de intercâmbio mais sólido e permanente com os mercados do Terceiro Mundo -, a política externa para com os países árabes tinha como objetivo principal e imediato minimizar o problema do balanço de pagamentos, haja vista a estratégia econômica nacional, que apostava em modelo baseado na utilização de energia importada barata. A industrialização brasileira tornava necessária a expansão de mercados para os produtos industrializados e os serviços produzidos no país, especialmente na América Latina, na Ásia, na África e no Oriente Médio.

Nesse sentido, o "Pragmatismo Responsável” do presidente Geisel ampliou e consolidou o modelo substitutivo de importaçóes, no contexto da conquista de mercados no exterior para as manufaturas brasileiras. $\mathrm{O}$ projeto de consolidação do modelo substitutivo de importações permitiu a intensificação de contatos comerciais com a África, a China Comunista e o Oriente Médio. No que diz respeito a este último, o Itamaraty adotou agressiva política exportadora de produtos industriais e serviços em troca do fornecimento de petróleo. Mais tarde, durante o governo Figueiredo, foi permitido inclusive a instalação de escritório de representação da Organização para a Libertação da Palestina em Brasília - tendo em vista angariar a simpatia geral dos países árabes exportadores de petróleo -, ainda que o então embaixador de Israel em Brasília afirmasse ter esperanças de que o país não reconhecesse uma "organização terrorista". 53

Entretanto, os esforços brasileiros para penetrar no Oriente Médio, durante as décadas de 1970 e 1980, foram tardios, por haverem sido determinados pela elevação do preço do petróleo. De modo geral, as relações com a região, durante o período, foram profícuas no sentido de aumentar razoavelmente a exportação de manufaturados, semimanufaturados e serviços brasileiros. Com efeito, em 74, o país exportava para a região cerca de US\$ 198 milhões e, em 79, passou a exportar US\$ 975 milhões. Todavia, o déficit permaneceu elevado durante toda a década em função das elevadas importações de óleo, que haviam passado de US\$ 353 milhôes, em 74, para cerca de US\$ 3,7 bilhões em 79. ${ }^{54}$ Durante a década seguinte, o Brasil

\footnotetext{
53 SANTANA, Carlos Ribeiro. O Brasil e as tensōes permanentes no Oriente Médio: a questão palestina. Dissertação de Mestrado. Brasília: Instituto Rio Branco, 2006, p. 78.

${ }^{54}$ SILVA, Heloisa Conceição Machado da, Op. cit., p. 589.
} 
continuou a fornecer produtos industrializados ao Oriente Médio, mormente, material bélico ${ }^{55}$. O aumento do comércio com os países árabes, embora pequeno, foi significativo do ponto de vista de que praticamente inexistia comércio anteriormente.

O incentivo do governo Geisel à criação de fontes alternativas de produção de energia, de modo a diminuir a dependência do petróleo, foi um dos fatores mais positivos da conjuntura internacional desfavorável da época. Dessa forma, um dos principais efeitos benéficos da crise energética, no médio e longo prazo, foi a capacitação nacional para a extração e o refinamento de petróleo pela Petrobras. Desde o primeiro choque, os governos militares incentivavam a produção nacional de petróleo; entretanto, a partir do segundo choque, a exploração de novos poços tornou-se mais viável, haja vista o elevado preço do barril de óleo no mercado internacional. Além disso, observou-se, no plano diplomático, o aumento da integração econômica e do conhecimento logístico e operacional do mercado árabe. A transformação do terceiro mundo em parceiro comercial do país impulsionou a reavaliação das prioridades internacionais da agenda diplomática.

Por fim, os resultados da busca pela expansão das relações comerciais com os países árabes, durante o período, deixaram a desejar. Ainda assim, a política pragmática - inserida em contexto internacional em que o Brasil foi coagido a aproximar-se do Oriente Médio - teve, sem dúvida, muitos aspectos positivos no tocante à busca por uma solução para a crise energética da década de 1970. Nesse sentido, apesar de não ter atingido o objetivo de aprofundar o intercâmbio comercial com os países árabes, a política externa de relações não-excludentes com países centrais e periféricos contribuiu para ampliar o leque das relações internacionais do país.

Recebido em 17 de março de 2006

Aprovado em 18 de agosto de 2006

\section{Resumo}

A intensificação da aproximação com o Oriente Médio, a qual preencheu certos vazios diplomáticos da atuação brasileira, está associada à crise energética da primeira metade da década de 1970 e ao projeto nacional de desenvolvimento econômico. Diante da alta do preço do petróleo, garantir o seu fornecimento consistia questão crucial para o país. A política externa da época inseriu-se no conteúdo da ação pragmática segundo a qual

\footnotetext{
55 As exportações de material bélico constituíam-se principalmente de armas de fogo, tanques leves, carros de combate, mísseis ar-ar, aviôes de contra-insurreição, jatos de treinamento e outros produtos bélicos. $\mathrm{Na}$ década de 1980, as guerras na região permitiram a experimentação e o aprimoramento dos armamentos produzidos pelo Brasil. Os principais clientes do país eram Líbia, Irã e, sobretudo, Iraque. Idem, ibidem, p. 589.
} 
o relacionamento diplomático deveria ser intensificado à medida em que crescia a sangria de divisas com a importação de petróleo, o que contribuiu para ampliar o leque das relações internacionais do país naquela região.

\section{Abstract}

Faced with the energy crises of the 70's Brazil pursued a natural model of economic development that led to strengthening its ties with the Middle East, which filled a certain diplomatic vacuum in Brazil's foreign policy. With high oil prices, securing its supplies was a crucial issue to the country. In an international context that forced Brazil to strengthen its political ties with the Middle East, foreign policy action was then geared to pragmatic ends, which meant that diplomatic relation should be intensified as foreign exchange losses grew with oil imports, something which contributed to the diversification of Brazil's relations with the countries in that region.

Palavras-chave: Brasil, Oriente Médio, Choque do Petróleo, Política Externa. Key words: Brazil, Middle East, Oil Crisis, Foreign Policy. 